\title{
In-group and Out-group Biases in the Marketplace: A Field Experiment during the World Cup*
}

\author{
Sang-Hyun $\mathrm{Kim}^{\dagger} \quad$ Fernanda L. Lopez de Leon ${ }^{\ddagger}$
}

May 2018

\begin{abstract}
We investigate the effects of group identity on discrimination by conducting an audit study in electronics markets in São Paulo, Brazil during the 2014 Brazil World Cup (WC). We manipulated buyers' group membership, by making them wear shirts of national football teams, and exploit the outcomes of the WC matches, which arguably affected the salience of sellers' group identity. Although we find that foreigners are overcharged, we do not detect discrimination against buyers wearing a rival team shirt. In contrast,

*We are grateful to Gabriela Barufi, Edward Cartwright, David Hugh-Jones, Joo Young Jeon, Ilyana Kuziemko, Charles Noussair, Ernesto Reuben, Judy Rich, Judit Temesvary, seminar participants at University of East Anglia and Yonsei University, and audience at 3rd Antigua Experimental Economics Conference for helpful comments. We thank Leonardo Rosa, Silvio Doria, Pamela Felix, Solange Goncalves, Ilaria Masiero, Robert McDonell, Erika Medina, Mayra Nagase, Paula Thais, Ghitz Sqalli, Arthur Souto, Fabiana Souza, Francisco Urdinez, Murilo Zacareli and other students at Universidade de São Paulo and Fundação Getulio Vargas for excellent research assistance. We thank Daniel Monte and Angelica da Silva Almeida for helping with the advertisement for recruitment. Sang-Hyun Kim gratefully acknowledges financial support from National Research Foundation of Korea Grant funded by the Korean Government (NRF-2014S1A5A2A03065638). This project was approved by the Internal Review Board of the University of East Anglia.

${ }^{\dagger}$ School of Economics. Yonsei University. E-mail: kimsan46@gmail.com

${ }^{\ddagger}$ School of Economics. University of Kent. E-mail: f.de-leon@kent.ac.uk
\end{abstract}


we do detect in-group market favouritism (i.e., lower prices) towards buyers wearing the Brazil shirt when Brazil had won a match in the very recent past. Our analysis rejects the explanation that sellers' behaviour were motivated entirely by economic profits. Instead, the results are more consistent with the taste-based discrimination theory (Becker, 1957), and shed light on the ways in which in-group and out-group biases occur in market outcomes.

JEL Classification: C93, D71, J15

Keywords: in-group and out-group discrimination, bargaining in the marketplace

\section{Introduction}

Group identity is of key importance in understanding social behaviour. Many of us tend to feel more comfortable with people in the same group (or those who are similar to us) than with ones from another group (or those who are significantly different from us), and these feelings are likely to affect our interactions with others in everyday life.

Despite the substantial body of literature demonstrating the importance of group preference in non-market interactions (e.g. Chen and Li 2009, Eckel and Grossman 2005, Fong and Luttmer 2009, Goette et al. 2006, and Shayo and Zussman 2010), in the laboratory market (e.g. Ball et al. 2001 and Li et al. 2011), and in labour markets (e.g. Bertrand and Mullainathan 2004 and Neumark 1996), the evidence from the field that such biases play a non-trivial role in goods markets has thus far been relatively rare. In contrast, recent field studies suggest that the marketplace discriminations are largely motivated by economic profits, not by a distaste toward people from other groups (Castillo et al. 2013, Ewens et al. 2014, Gneezy et al. 2012, List 2004, Zussman 2013).

The contrast mentioned above mirrors a larger debate in the literature, which has been developed around two explanations for the discrimination in the market (for reviews, see Gneezy et al. 2012, Guryan and Charles 2013, and Rich 2014). The first one, put forward by Gary Becker in his work "The Economics of Discrimination" (1957), simply regards discrimination as an outcome of agents' preferences and 
prejudices. A seller may discriminate buyers out of her religious belief or prejudices against other ethnic or social groups, even though she knows well that doing so may reduce her economic profit. The other explanation, proposed by Phelps (1972), is a statistical discrimination theory according to which purely rational agents treat individuals differently due to incomplete information. When a seller does not know much about her trading partners, it is rational for her to discriminate between buyers from different groups because these memberships (e.g. nationality) may signal unknown profit-related characteristics of the buyers (e.g. income or willingness to pay).

This paper sheds new light on this discussion by proposing a novel experiment to understand whether and how in-group and out-group preferences affect bargaining outcomes in real markets. We conducted an audit study in informal electronics markets in São Paulo, Brazil, during the 2014 Brazil World Cup championship (WC). In these markets, prices are very often determined by bargaining. For the study, we employed Brazilian (in-group) and non-Brazilian (out-group) experimenters to negotiate with local sellers. Following a fixed bargaining script similar to the one used in Castillo et al. (2013), our experimenters enquired about relatively inexpensive and homogeneous electronic products such as a PlayStation game, headphones, and memory cards. In total, we recorded the behaviour of 557 sellers in 918 market interactions before and during the championship. To detect the evidence of discrimination on the supply side of the market, we analyse the prices offered by sellers and the likelihood of a seller to accept the buyer's price. ${ }^{1}$

To examine whether sellers' preferences indeed affect bargaining outcomes, we

\footnotetext{
${ }^{1}$ Other recent studies consider marketplace discrimination from a demand-side perspective. Ayres et al. (2015) and Doleac and Stein (2013) investigate the racial discrimination in online markets adopting similar treatments, both of them manipulated the seller's racial identity by using images of the product held by a hand with different skin colours. Doleac and Stein (2013) examined online markets in which the final transactions are conducted in person, and report heterogeneous effects of the skin colour which are consistent with the statistical discrimination theory. On the other hand, buyers and sellers did not meet in person in the study of Ayres et al. (2015), and the authors argue that the observed discriminations were likely driven by rapid and intuitive judgement (the so-called "system I").
} 
manipulated the salience of buyers' group membership - groups based on their support for Brazil or another team - by making them wear shirts of national football teams. In-group (i.e., Brazilian) buyers wore the Brazil shirt, and outgroup (i.e., non-Brazilian) buyers wore a shirt of one of the following teams: Chile, Croatia, Mexico, or Spain. We randomized the group of sellers to whom the buyers' football shirts were visible (the treatment) or hidden by a jacket (the control) during negotiations. ${ }^{2}$ This treatment on the buyers' outfit allows us to quantify discrimination in a very controlled way by making within-buyer comparisons. ${ }^{3}$

Since the football shirts could signal more than just group memberships (for instance, the buyers' wealth), we focus on variations, as opposed to the average level, of the effect of shirts over the course of the WC. More specifically, we make use of the fact that the Brazil matches induced exogenous fluctuations in sellers' emotions toward buyers wearing specific shirts (in line with the psychology studies, as reviewed in Esses et al. 1993). ${ }^{4}$ We conjecture that a victory for Brazil would intensify the feeling of national pride among sellers and hence increase in-group favouritism, and test this hypothesis by looking at the impact of the Brazil shirt on the bargaining outcomes before and after Brazil won a match. We also test for out-group bias by examining whether non-Brazilian buyers were more discriminated against when they were wearing a shirt of an imminent rival of Brazil (e.g. when buyers wore the Croatia shirt one day before the Brazil vs. Croatia game) than in another situation. ${ }^{5}$

\footnotetext{
${ }^{2}$ It is needless to say that Brazil is very well known for its passion for football, which peaked during the WC as the country hosted the championship (See for instance "World Cup Survival Guide", New York Times, 2014). This made the connection between football shirts and the categorization of buyers into in-group or out-group natural to the market environment.

${ }^{3}$ More precisely, because our experimenters changed their outfits a few times in each day, and many of them visited the markets several times over the WC, we can include buyer- and time-fixed effects as well as other control variables in our regressions. This allows us to control for unobserved variables that other audit studies that make between-buyer comparison cannot. Our identification strategy is outlined in Section 2.

${ }^{4}$ In this regard, we also take inspiration from Edmans et al. (2007), who conclude that the news of their own country's defeat in the WC affected investors' mood and thus financial market outcomes.
}

${ }^{5}$ Surveys are also used to identify motives of discrimination (Oreopoulos 2011, Zussman 2013). 
In between- and within-buyer comparisons, we find no notable impacts of team shirts on market outcomes, when worn either by Brazilians or by non-Brazilians buyers; however, we do detect statistically and economically significant changes in the effects of shirts over the course of the WC. In particular, when Brazil had won a WC game in the recent past, sellers offered significantly lower prices to and were more likely to accept offers from Brazilian buyers wearing the Brazil team shirt. We also find that after Brazil's victory, a cheap, unofficial Brazil shirt and the expensive, official one are equally effective in inducing market favouritism. This, of course, does not imply that statistical discrimination does not play a role in the market. We actually observe a pattern consistent with the statistical discrimination theory: on average, buyers were offered higher prices when wearing the expensive shirt than when wearing a jacket, while the cheap shirt did not trigger such discrimination.

In contrast, we do not detect evidence of out-group bias in the negotiation outcomes. As opposed to our initial hypothesis, sellers did not significantly discriminate against buyers who wore the shirt of Brazil's imminent opponent. The prices given to those buyers were not statistically different from those given to foreign buyers wearing shirts of non-rival teams. However, sellers were less likely to provide verbal help to these "rival" buyers, which in itself may suggest the existence of some group preference that seems not to have manifested in market outcomes.

As mentioned above, our results add to the scarce literature on product market discrimination based on group preferences. A few experimental studies investigating the existence and patterns of discrimination against foreigners include Balafoutas et al. (2013) and Oreopoulos (2011). In a similar vein, we find that nonBrazilian buyers are overcharged in comparison with Brazilians. However, while the motivation behind the discrimination (taste-based or statistical) was not clearly revealed in their works, we specifically designed our experiment to detect taste-based discriminations, and do find evidence of such.

Also closely related to this paper are Zussman (2013) and Li et al. (2011). These We believe, however, that observing reactions to shocks has an advantage over post-experiment surveys in which respondents might be providing self-justification instead of revealing their true motive. 
studies find mixed results. Zussman (2013) investigates discrimination in an online market in Israel. He sent enquiring emails to sellers, manipulating buyers' names to be Jewish or Arabic. He found that sellers were more likely to reply to buyers with a Jewish name. ${ }^{6}$ To explain the motive for discrimination (i.e., statistical or taste-based), he correlates the discriminatory behaviour with attitudes in a postexperiment survey and concludes that the discrimination is based on a transactionrelated characteristic (i.e., Arabs in Israel are believed to be less trustworthy), giving support to statistical reasoning.

On the other hand, Li et al. (2011) do find effects of in-group bias on discrimination in a laboratory market experiment. The authors first grouped subjects by their preference for paintings (Kandinsky vs. Klee) or by their college major. Then, they randomly assigned the role of seller or buyer, and made subjects interact repeatedly in a market of three buyers and three sellers. It turned out that sellers were more likely to make offers to in-group buyers and that buyers were more likely to accept offers from in-group sellers. Unlike the current article, these studies focus on the likelihood of transaction among agents from different groups, rather than bargaining outcomes. ${ }^{7}$

This paper proceeds as follows. In Section 2, we state our identification strategy and hypotheses. Section 3 explains the markets and the experimental procedure. Our hypotheses are tested in Section 4, and Section 5 concludes. The Appendix provides the results of robustness checks.

\section{Identification Strategy and Hypotheses}

Following classical studies in social psychology and more recent ones in economics (see, e.g., Benjamin et al. 2010, Chen et al. 2014, Perdue et al. 1990 and Shih et al. 1999), we quantify in-group and out-group biases by priming buyers'

\footnotetext{
${ }^{6}$ Arabs are the minority and are thus more likely to be out-group members.

${ }^{7}$ In this sense, their results speak more to the literature on homophily which refers to the empirical fact that people tend to interact with similar others. Our paper does not address this issue because, as will become clear later, matching of a buyer and a seller was not a choice of either of them.
} 
group identity to sellers. The priming technique involves the activation of social representations - by exposing subjects to some information reminding them of their or others' social identity - and the application of these activated representations in social behaviour (Bargh 2014 and Molden 2014). For instance, Perdue et al. (1990) conducted experiments mixing the pronouns "us" and "them" (referring to in-group and out-group status) with other syllables so as to understand how these pronouns affect the way information is processed. Chen et al. (2014), on the other hand, conducted an experiment among Asians and Caucasians, exploiting their natural identities (i.e., their ethnicity or their school affiliation) to identify the effects of in-group and out-group bias on coordination and cooperation in games. To prime subjects' identity, Chen et al. used a pre-experiment questionnaire on family and cultural background (in ethnic identity treatment) or one on personal experience when applying for the university (in school identity treatment). ${ }^{8}$ Closer to the manipulation used in this paper, Morita and Servátka (2013) induce in-group identity among subjects by making them wear team uniforms.

In our study, shirts of national football teams are used to highlight buyers' association with sellers: some buyers are rooting for group Brazil ("us") and others for another national group ("them"). ${ }^{9}$ During the WC, football team shirts were a very popular item in Brazil, and wearing one was a way to demonstrate one's national pride and support for the country. According to the press, stores predicted a $500 \%$ increase in the demand for the official shirt of the Brazilian national team as well as a large increase in the demand for the shirts of non-Brazilian teams due

\footnotetext{
${ }^{8}$ Although priming techniques are now popularly employed by experimental economists, they may seem contradicting to the assumption of rational agents, upon which most of the main stream economic theories are built. However, there are quite a few theoretical studies demonstrating that endogenous (and potentially primable) identity can be fruitfully introduced in the rational agent framework. See for example, Benabou and Tirole (2011) and Akerlof and Kranton (2010).

${ }^{9}$ Research on the social psychology of sports documents that individuals report more positive evaluations of other in-group fans than of rival out-group fans (Wann and Grieve 2005, Wann et al. 2001), and show more pro-social behaviour towards fans of the same team (Platow et al. 1999). Others studied the effects of priming national symbols. For example, Hassin et al. (2007) conducted experiments exposing subjects to their national flag and find that it increased the sense of unity among the participants, drawing them to the political centre.
} 
to the large influx of tourists. ${ }^{10}$

Therefore, we believe that the football shirts, by making buyers' identity more salient, did prime sellers' group identity, and hence could stimulate sellers' ingroup favouritism and out-group discrimination. ${ }^{11}$ So, we hypothesize that, due to the more salient representation of group identities, Brazilian buyers will be more favourably treated when wearing the Brazil shirt and that non-Brazilian buyers will be more discriminated against when wearing a non-Brazil team shirt.

However, these simple hypotheses cannot be directly tested, because football shirts may demonstrate buyers' characteristics other than their group identity. More precisely, the effect of wearing a shirt can be decomposed into three parts:

$$
\begin{aligned}
\text { Shirt effect } & =(\text { Signalling WTP })+(\text { Baseline group identity }) \\
& +(\text { Group identity triggered by the WC })
\end{aligned}
$$

First, a football shirt may signal a buyer's transaction-related unobserved characteristics such as her willingness to pay (WTP). For instance, when a buyer is wearing a shirt of a high-income country, a seller would infer that the buyer's income level is likely high. Also, when a Brazilian buyer is wearing an official team shirt that is rather expensive and will become less fashionable when the championship is over, a seller may expect the buyer's income to be high. In these cases, the seller may play tough during the negotiation.

Second, sellers may genuinely like or dislike some countries and their citizens more than others ("Baseline group identity" in the above equation). For example, Brazilians may feel closer to Chileans than to Croatians because Chile is on the same continent. Although this tendency, if it exists, should be regarded as an impact of group identity, there are at least two problems in estimating this effect:

\footnotetext{
${ }^{10}$ About the prediction, see http://jcrs.uol.com.br/mob/noticia.php?codn=164715. Also, during the WC the number of tourists in Brazil was estimated as about one million.

${ }^{11}$ An alternative interpretation of a team shirt (as opposed to a national symbol) is that it reveals the buyer's taste for football. But during the WC, the distinction between football fans and the others was very blurred as described for instance, in a New York Times article "Making Holidays of Brazil's World Cup Games" (2014). Besides, as will become clear shortly, our formal tests are unlikely to be affected by this "noise."
} 
(i) it is difficult to isolate this effect from other confounders (e.g. the effect of signalling income), (ii) more importantly, in order to estimate this effect on bargaining outcomes, we first need a reliable measure of psychological proximity between Brazilian sellers and buyers from different countries. However, we do not have such a measure.

Because of the first two effects (i.e., "signalling WTP effect" and "baseline group identity effect"), we do not know the sign of the total effect of wearing a football shirt. Therefore, we focus on the effects of group identities that are triggered or strengthened by the WC games. To do so, we compare the effect of team shirts before and after Brazil's matches, taking a difference-in-differences approach. Since we have visited the markets over a relatively short period of time (from 30 May to 7 July, 2014), most factors affecting sellers' perception of buyers' economic status (e.g. GDP of the country and the cost of visiting Brazil) have stayed constant during the period. Because the most significant event during the period was the $\mathrm{WC}$ football games, which greatly stimulated nationalistic emotions, it is safe to assume that any detected changes in the effect of a football shirt are attributable to the outcomes of the games making sellers' sense of national identity more (or less) salient. ${ }^{12}$

Then, how exactly do the football games affect the sense of group identity? It is well-documented in the psychology literature that emotions are a major determinant of group attitudes (Esses et al. 1993). Negative emotions such as hostility play a role in the exacerbation of prejudice (Allport 1954), and more related to the hypotheses in this experiment, anxiety and distress triggered by competition exacerbates negative evaluation of out-groups (Wilder and Shapiro, 1989). This also has been noted by economists, most notably Sen (2007), who conjectured that group identities play an important role in escalation of conflicts between groups. According to this theory, a conflict between groups strengthens group identities, which may engender more conflicts afterward. We thus examine the effect of direct and imminent rivalry in

\footnotetext{
${ }^{12}$ One may think of the possibility that the effects of the WC games are long lasting and evolve in a complex way. Instead, here we follow Edmans et al. (2007), who focus on the effect of a very recent sports game. Jones et al. (2012) find that the positive emotional state associated with winning in a sports game persists for approximately four days, which seems to suggest that our method would be good enough to show the main effects of the matches.
} 
the WC on the sellers' behaviour toward out-groups, by focusing in a time in this rivalry is most exacerbated.

For the identification of in-group biases, we focus on the role of positive emotions by investigating the case of Brazil's victory. The reasoning is that the victory triggers a stronger sense of national identity. Any individual can fit in many groups. For example, a black Brazilian woman can fit into at least three (female, black, and Brazilian). When Brazil wins, this hypothetical individual feels prouder to be Brazilian and this particular identity becomes relatively more salient. Some of the related evidence are in Crocker and Luhtanen (1990) who reported that people react to changes in the collective self-esteem by increasing their in-group evaluation. Cialdini et al. (1976) discovered that students used the pronoun "we" more often when describing a victory compared to a non-victory by the football team of their school. $^{13}$

The following are the hypotheses of this study:

H1 In-group bias: The effect of the Brazil shirt on market favouritism will increase just after Brazil wins a match; the Brazil shirt will be more effective in motivating sellers to charge lower prices and accept buyers' offers.

H2 Out-group bias: The effect of a non-Brazil shirt on discrimination will increase when the respective team is about to play against Brazil; the non-Brazil shirt will be more effective in motivating sellers to charge higher prices and to reject buyers' offers.

If the market is always cold and rational, as the statistical discrimination theory presumes, both hypotheses will be rejected. Instead, if we find a significant effect of the WC matches, it will imply that the market is not always rational, which in turn suggests that the statistical discrimination cannot alone explain all of the marketplace discriminations. To test these hypotheses, we collected data at informal

\footnotetext{
${ }^{13}$ It is also possible that a defeat leads to a decrease of in-group association. Bizman and Yinon (2002) found that basketball fans tend to refuse to take a team poster and to avoid other fans after a defeat. In this study, however, we do not consider the effect of a defeat mainly because it seemed too dangerous to visit the markets after the defeats of Brazil-especially when angry fans poured out into the street after the semi-final in which Brazil was defeated 1-7 by Germany. 
electronics markets before and during the WC as detailed in the next section.

\section{The Experiment}

\subsection{Markets}

The experiment was conducted in electronics markets in São Paulo. We focused on two main markets. The first one, Mercado Santa Efiginia, has more than 1,300 stores on seven streets (Santa Ifigênia, Aurora, Vitória dos Andradas, Timbiras, General Osorio and Gusmoes). The second one, Mercado Paulista, consists of two malls located at Avenida Paulista, which are in a more cosmopolitan area of the city. The first mall (Market Paulista) has 146 stores, and the second (Stad Center) 204 stores. These markets play an important role in the commerce of São Paulo, and their prices are very often determined by bargaining.

\subsection{Dates of visits}

Before the WC got started, given their high likelihood of playing against Brazil, four teams - Chile, Croatia, Mexico, and Spain - had been chosen to be the outgroup teams. Croatia and Mexico were in the same group with Brazil at the first stage. At the round of 16, either Chile or Spain was expected to compete against Brazil, and it turned out that Chile was the one. So, we visited the markets one day before and two days after the following three matches: Brazil vs. Croatia (12 June), Brazil vs. Mexico (17 June), and Brazil vs. Chile (28 June). We also collected data two weeks before the first game (30 and 31 May) and one day before the Brazil vs. Germany match (8 July). The set of shirts worn on each visit and the score for each match are shown in Figure $1 .^{14}$

On all nine days, for the test of in-group bias hypothesis, we had Brazilian buyers wear the official Brazil shirt, and on some days (before and after Croatia and Chile games) they also wore cheap non-official shirts to test whether income consideration plays a major role as further explained in Section 4.

\footnotetext{
${ }^{14}$ The structure of the WC tournament is explained in Figure A1 in the Appendix.
} 


\section{Figure1}

To test the out-group bias hypothesis, we made non-Brazilian buyers wear the shirt of Brazil's competing team before and after the first three matches. ${ }^{15}$ To disentangle an in-group bias from a favouritism toward a winner, we also had nonBrazilian buyers wearing a shirt of a team that had just won (e.g. Chile on 14 June) or that had just been defeated (Spain on 20 June and Mexico on 30 June) against another team than Brazil.

\subsection{Buyers and Products}

Our research assistants were sent to the market in pairs. Each person was assigned a role as a buyer or a buyer's friend. There were two types of pairs: a Brazilian pair consisting of a Brazilian buyer and a Brazilian friend and a nonBrazilian pair consisting of a non-Brazilian buyer and a Brazilian friend. The experimental manipulation on the outfit was only on the buyer who conducted the entire negotiation, always in Portuguese, following a fixed script. The role of the friend was to observe the buyer and protect him/her from any possible threat or physical attack, especially when non-Brazilian buyers were wearing the shirt of a team playing against Brazil. Also, due to the possibility of pickpocketing and other crimes, it is very unusual that a tourist would go to Mercado Santa Efiginia on his/her own. It is more natural for a local to bring his/her foreign friend to this market to find a bargain.

This pairing could have attenuated possible group biases, but it was important to make the exercise more convincing and to ensure the safety of experimenters. However, it is worth emphasising that his/her only line was to ask for a business card from the store after the negotiation had been concluded. The full script is described in the Appendix. Hence during the bargaining it was not straightforward to tell whether the friend was a local or a foreigner.

\footnotetext{
${ }^{15}$ Since our in-group bias test relies on a victory of Brazil and due to our budget constraint, we did not collect data on days after the matches in which Brazil was defeated.
} 
In total, we had 41 pairs, combinations of 22 Brazilians and 13 non-Brazilians. Brazilians were undergraduate and graduate students at Universidade de São Paulo or at Fundação Getulio Vargas. Non-Brazilian participants were exchange students at the same schools, who had been in Brazil for at least one semester. All of them spoke Portuguese with a foreign accent. They were recruited from an internship program in these institutions or via advertisements on the Facebook pages of the students' organizations. ${ }^{16}$

Buyers enquired for homogeneous electronic products to minimize any potential confounding factors related to product characteristics. The products were Sony headphones XZ 300 and XZ 100, a Sandisk memory card 32 GB and 8 GB, and the 2014 FIFA World Cup games for PlayStation. Pictures of the products are included in the Appendix. In selecting these products, we follow two main criteria: the product had to be available in most of the stores (this was noticed during the pilot) and must be products that a tourist could be interested in buying during a short trip abroad for the WC.

\subsection{Negotiation}

Each pair was in the market for about 2 hours each day. They were assigned to a route, and they visited some stores on the route, such as those of which addresses end with an odd number. ${ }^{17}$ To increase the chances of collecting bargaining outcome data, the pair was instructed to look for the selected products in the store window and to enquire for whichever product that was most likely to be available. In each store, the pair followed a fixed script very similar to the one proposed by Castillo et al. (2013), ${ }^{18}$ starting with the buyer asking, "Do you sell product X?"

\footnotetext{
${ }^{16}$ During the recruitment phase, all participants responded to a questionnaire in which they were asked whether they would feel uncomfortable shopping while wearing specific team shirts or shopping with someone who is wearing these shirts. We did not allocate anyone to a condition in which he/she would feel uncomfortable. To avoid experimenter biases, research assistants were informed neither of the research questions nor the expected results of this study

${ }^{17}$ We never sent two pairs of buyers to the same route in the same day, and no pair of buyers repeated the same route over the $\mathrm{WC}$.

${ }^{18}$ Castillo et al. (2013) investigate Peruvian taxi drivers' patterns of discrimination regarding the gender of passengers. The authors made their taxi customers negotiate with taxi drivers, using
} 
In the case that the product was available (77\%), the buyer asked "How much does it cost if I pay in cash?" After the seller gave the quote, the buyer insisted on the pre-determined maximum acceptable price. ${ }^{19}$ Buyers repeated this response twice in case that the seller made any counteroffer. Then, the buyer terminated the negotiation, the buyer's friend asked for the store's business card, and the pair left the store. In the case that the seller accepted the offer, the buyer said he/she would make a phone call to confirm the purchase or get some cash from an ATM. ${ }^{20}$

In the case that the product was not available (23\%), the buyer asked for directions for the nearest subway station. We recorded whether the seller refused to provide any help $(7.9 \%=17 / 198)$, and interpret largely as a non-profit measure of discrimination. This behaviour is more likely to be driven by sellers' feelings and taste preferences.

In addition to memorizing this information, each participant was asked to report on a number of details about the store, the seller and how the buyer was treated during the visit. Immediately after leaving the store, they made a phone call to one of our interviewers who read the questions and recorded the outcomes. The buyer and the friend were instructed to speak on the phone separately from each other in order to avoid affecting each other's answers. Since the shirt could have affected the buyer's attitude (e.g. despite the script, a victorious shirt might have turned buyers into better negotiators), we asked the buyer's friend to evaluate the buyer's level of confidence during the negotiation. In Table A1 in the Appendix, we present the regression results showing that the shirts are very largely uncorrelated with the buyers' attitude. In results not shown in the paper (available under request), we find that main regression results do not change if we include this assessment as an explanatory variable.

a fixed-offer bargaining script that we follow closely in this study. Castillo et al. find evidence of discrimination against male passengers, which they conclude is driven by statistical discrimination.

${ }^{19}$ We established a low but reasonable maximum acceptable price for each product by choosing the third lowest price in an online Brazilian market (http://www.buscape.com.br/eletronicos.html). More specifically, the prices that we used were: 115 reais for Sony headphones XZ 300, 78 reais for Sony headphones XZ 100, 52 reais for Sandisk memory card 32 GB, 18 reais for Sandisk memory card $8 \mathrm{~GB}$, and 140 reais for FIFA World Cup game.

${ }^{20} \mathrm{It}$ is a common practice to enquire about prices and not to buy. 
An obvious concern was to keep the experiment anonymous to sellers. It was rare that a buyer visited the same store more than once (only 11 cases or $2.44 \%$ of the total interactions), and only $21.7 \%(10.4 \%)$ of the sellers were asked for the same product more than once (twice) over the whole experiment. We believe that the phone calls were not suspicious, as it is common for people to discuss price before making a purchase.

\subsection{Randomization}

We randomized whether our buyers were to wear a football shirt or a jacket hiding the shirt. To control for income-related factors as much as possible, we provided jackets that were priced similarly to the official team shirts worth approximately 100 US dollars. More precisely, in Mercado Santa Efiginia, each pair was assigned to a street route that had 6 to 8 blocks, and they visited 2 to 4 stores on each block. Every time they were about to move on to the next block, the buyer made a phone call, and the interviewer rolled a dice to determine the treatment allocation: whether to hide the team shirt by wearing the jacket or to show the shirt. We chose to conduct the randomization at the block level instead of at the store level in order to avoid a situation in which a seller sees the buyer's shirt in the street when they are assigned to the "jacket condition" and vice versa. ${ }^{21}$

In Mercado Paulista, we follow a similar procedure. We explored the internal logistics of the malls to identify clusters of stores that were separated by walls, thus limiting sellers' vision. Randomization was conducted at this level.

In total, we collected 918 interactions of buyers with 557 sellers. Table 1 shows the number of negotiations by market, pair, and treatment. In Table A2 in the Appendix, we show evidence that visits were randomly assigned across stores. Mostly, we do not find statistically significant correlations between treatment

\footnotetext{
${ }^{21}$ On some days, Brazilian buyers had to wear a cheap unofficial Brazil shirt as well as the expensive official Brazil shirt. On these occasions, in the first half of a day, they would wear one of the two Brazil shirts, change their clothes during a short break, and continue the experiment in the second half. (The shirt order was randomized.)
} 
conditions and store characteristics or enquired product.

\section{Table1}

\section{Results}

We begin by documenting how the outcomes - sellers' initial price, second price, and the likelihood of a seller to accept the buyer's price - varied depending on a buyer's nationality. The first price quote would entail both sellers' group preference and their expectation on buyers' willingness to pay based on his/her group identity, the latter of which is updated in the second price. Then, the probability of accepting the buyers' offer would disclose more about the sellers' willingness to trade based on their group preference, because buyers' WTP had been revealed through the bargaining process. ${ }^{22}$

In Table 2, we present results for the impact of buyers' nationality - the effect of being Brazilian - with different sets of controls. Each entry represents estimates from a separate regression. The numbers in parenthesis are robust standard errors, clustered at the address level. ${ }^{23}$

\section{Table 2}

Although our buyers visited stores 918 times altogether, price quotes were given only in 697 cases due to the availability of the products. In 103 interactions (20.7\%), sellers stated prices below the maximum acceptable one, and in 42 cases (6\%) they refused to make any counteroffers. In the remaining 553 cases $(73.3 \%)$, sellers made second price offers.

\footnotetext{
${ }^{22}$ Obviously sellers' expectation about buyers' impatience may also play a role. In some occasions, sellers' agreed on the price after the negotiation was concluded and our experimenters were leaving the store. We recorded these cases as if sellers have accepted the price.

${ }^{23}$ Recall that we visited two markets: "Mercado Santa Efiginia" and "Mercado Paulista". The latter consists of two malls. "Address" refers to the mall where the store locates in the case of "Mercado Paulista". "Mercado Santa Efiginia" is a street market, and "address" refers to the street where the store is. A large chunk of our observations (58\%) come from Rua Santa Efiginia. For this street, the variable "address" is defined at the street-block level.
} 
Note first that the estimated impact is robust across specifications with different sets of controls. The first column shows the results for the simplest specification, including only a constant and product fixed effects. To produce the second column, we add to the first specification street fixed effects and other covariates that control for demand effects: day (eight dummy variables) and time of the visit fixed effects (seven indicators of one-hour blocks, from 10-11am to 4-5pm). In column (3), buyerpair random effects are added to the regression. In the most complete specification [column (3)], we find that Brazilians were given initial price quotes about $6.3 \%$ lower than non-Brazilians. For the second price, the difference across buyers' nationality declined but did not disappear. On average, foreign buyers were offered $5.4 \%$ higher second prices in comparison to Brazilian buyers. We find that the correlation between the likelihood of sellers' acceptance and the buyer's nationality is not statistically significant (p-value $>0.19$ ) [the third row in column (3)]. These results seem consistent with the statistical account that the differential treatment initially given to Brazilians (supposedly better informed customers) vanishes over the bargaining process, as non-Brazilians present themselves as tough negotiators.

Next, we proceed by testing the two hypotheses presented in Section 2. To test the in-group hypothesis (H1), we estimate the following equation utilizing only the sample of Brazilian buyer pairs.

$$
Y_{i j t}=\gamma_{j}+\pi_{1} \times \operatorname{shirt}_{i j t}+\pi_{2} \times \text { shirt }_{i j t} \times \text { victory }_{t}+X_{i j t} \beta+\eta_{i j t}
$$

where $Y_{i j t}$ is one of the bargaining outcomes for negotiation $i$ of buyer $j$ at time $t, \gamma_{j}$ are buyer-pair fixed effects, and shirt ${ }_{i j t}$ is the binary variable which assumes value 1 if the buyer was not hiding the football shirt during negotiation $i$ and 0 otherwise. victory $_{t}$ is 1 if sample $i$ was collected two days after Brazil's victory, and 0 otherwise. $X_{i j t}$ is the vector of covariates such as product and street fixed effects, and the indicators for day and time of the visit. ${ }^{24}$

The in-group bias hypothesis (H1) is that the effect of wearing a Brazil shirt increases when Brazil won a game in the recent past. Table 3 presents the estimates

\footnotetext{
${ }^{24}$ Note that victory ${ }_{t}$ does not appear in the equation because all the dummy variables for day of visit are included in $X_{i j t}$.
} 
of $\pi_{2}$ in different regressions. (The estimates for $\pi_{1}$ are reported in Table A3 in the Appendix.) Here we focus on the sample of Brazilian pairs, but the patterns found here remain the same when we use the entire sample (including Brazilian and non-Brazilian pairs) as reported in Table A4 in the Appendix. In regression analyses not reported in the paper, we checked whether the findings in Table 3 are sensitive to the choice of control variables using other simpler specifications, and we find practically the same results.

The first row in Table 3 tests for the market favouritism hypothesis (H1), that is, whether in-group biases were triggered by the football shirt just after Brazil had won a match. After a victory, the first price given to buyers wearing the Brazil shirt was about $2.5 \%$ lower than that charged to the same buyers wearing the same shirt in other occasions [column (1)]. However, this difference is not statistically significant. On the other hand, sellers turned out to be significantly more generous in their second price quote: the difference in the price was approximately $11 \%$, as shown in column (3). Sellers also became $33.5 \%$ more likely to accept these buyers' price offers when Brazil had recently won [column (5)]. It is worth noting that the identified effect may not be entirely driven by emotional sellers, because even a seller who himself was not affected by the treatment might have to offer discounts in response to other sellers doing so. ${ }^{25}$

Although it seems most natural to interpret our finding as a manifestation of in-group bias, it allows some interpretations for statistical discrimination as well. For instance, one may suspect that the effect of the shirt fluctuated in response to Brazil's victories because the number of buyers wearing football shirts, and therefore the signalling value of the shirt, fluctuates over the WC. To be specific, suppose that, while sellers gave price quotes according to their rational expectation toward the buyers' WTP, many buyers emotionally responding to Brazil's victory, purchased the expensive official shirt after a winning match. If this were the case, the team shirt would carry less information about the buyer's wealth after the victory than before. This might be the reason sellers charged lower prices to buyers wearing the football shirt just after Brazil had won.

\footnotetext{
${ }^{25}$ We thank an anonymous referee for pointing this out.
} 
To evaluate this interpretation (and other income-related explanations), we introduced an extra treatment. In addition to the official shirt worth of about 100 US dollars (229 reais), our buyers also wore a cheap, unofficial shirts worth approximately 7 US dollars (15 reais). Because the unofficial shirt did not signal the high income of the buyer in the first place, the above argument (and other interpretation in line with statistical discrimination theory) does not apply to this shirt. We proceed by decomposing the football shirts into two categories, official and unofficial, and estimate:

$$
\begin{aligned}
Y_{i j t} & =\gamma_{j}+\varphi_{1} \times \text { official }_{i j t}+\varphi_{2} \times \text { unofficial }_{i j t}+\varphi_{3} \times \text { official }_{i j t} \times \text { victory }_{t} \\
& +\varphi_{4} \times \text { unofficial }_{i j t} \times \text { victory }_{t}+X_{i j t} \beta+\eta_{i j t}
\end{aligned}
$$

The estimates of $\varphi_{3}$ and $\varphi_{4}$ are presented in the even numbered columns in Table 3. If income inferences drove the differential treatment in the first row, then only $\varphi_{3}$, not $\varphi_{4}$, should have been statistically different from zero. The results refute this scenario. The estimates indicate that not only buyers with the official shirt but also those with the unofficial one were charged a lower second price after Brazil had won a game (the magnitudes are statistically indistinguishable, $\mathrm{p}$-value $=0.71) .{ }^{26} \mathrm{In}$ addition, column (6) shows that the significant effect found in column (5) is largely driven by the sample of buyers with the inexpensive shirt. Compared with other occasions, after a Brazil victory, sellers were $51 \%$ more likely to accept the offer from a buyer wearing the unofficial shirt. These estimates are large and economically relevant.

\section{Table 3}

To test the hypothesis of out-group bias (H2), we investigate whether the impact of wearing the shirt of Brazil's competitor just before the match (e.g. the effect of wearing a Croatia shirt one day before the Brazil vs. Croatia game) differs from

\footnotetext{
${ }^{26}$ In Table A3 in the appendix, we report the full result of the regression. It turns out that buyers were offered higher second prices when wearing the expensive official shirt than when wearing a jacket (i.e., $\varphi_{1}$ is positive and marginally significant). In contrast, this is not observed with the cheap unofficial shirt. This pattern, on the other hand, is suggestive that some statistical discrimination is also present in the market.
} 
the effect on other occasions. We focus on the sample of non-Brazilian pairs. In regressions, we include the indicator variable for the treatment ( 1 if the non-Brazil football shirt was visible and 0 if it was hidden) and the interaction between the treatment indicator and a dummy for whether the football shirt is from the rival team. Again, we add controls for product, buyer, and street fixed effects, and the time and day dummies. The estimates of the coefficients of the interaction term for the rival shirt are presented in Table 4.

We find no statistically significant impact of being a supporter of the rival team on any of our outcome measures. We look for additional evidence, investigating the case of recently defeated teams. Since it is very rare to play the same team twice in the tournament, once a team is defeated, that team is very unlikely to be an opponent again. Thus, the reaction to a defeated team's shirt might be a mirror image (since it would be no longer a rival) of the reaction to a rival team's. Again, we do not find evidence that supports H2. In column 7 of Table 4, we look at the shirt's effect on the probability that the seller refuses to provide help with directions to the subway. We find weak evidence that sellers are less likely to help buyers wearing a shirt of Brazil's rival. They were approximately $22 \%$ less likely to provide an advice. This effect is statistically significant at the $5 \%$ level in specifications excluding some of the control variables (not shown in the text) and significant at the $10 \%$ level for a one tail test in the most complete specification, as shown in Table $4 .{ }^{27}$ These findings may suggest that sellers were less sympathetic toward out-group buyers although it did not substantially affect the negotiation outcomes, as revealed in the previous columns. ${ }^{28}$

\section{Table4}

Recall that the absence of evidence is not evidence of absence. In other words, it is possible that we fail to detect the evidence of out-group discrimination although

\footnotetext{
${ }^{27}$ We could not replicate the regressions with the sample of Brazilian buyers because Brazilian buyers could not have found the product that they wanted for only a very few times.

${ }^{28} \mathrm{~A}$ potential reason for this difference is that the cost of discrimination is much low for giving advice compared to a hiring or selling decision.
} 
it does exist, because, for example, the sample size is not large enough or because our experimental design somehow missed the "button." It is also possible, however, that our data well describe what was going on in the market: some sellers who have distaste for out-group members might consciously avoid to price discriminate.

Another caveat is the Heckman critique. Heckman and Siegelman (1993) and Heckman (1998) point out that when the outcome variable of an audit study is binary, the difference in the variance can confound with the difference in the mean, thus generating spurious results. For example, sellers could infer that there is a larger proportion of affluent buyers (with higher willingness to pay) among the group of individuals wearing the Brazil shirt than among buyers wearing the jacket. ${ }^{29}$ We believe, however, that our findings are not seriously undermined by the criticism. In our setting, a seller decides whether to accept the final price (the only binary variable among the outcomes) after several rounds of haggling, so the willingness to pay of the buyer would have been revealed, and at that point the inference above is unlikely to be relevant to the seller's decision.

\section{Conclusion}

In this paper, we investigate whether group identity biases have an impact on the negotiations in the marketplace. The results of our audit study show that foreigners are charged higher prices than local buyers, demonstrating that nationality matters. This is perhaps not surprising given the common perception that tourists are generally overcharged, due to, for example, their lack of experience/knowledge in the local market. This finding resembles those of Balafoutas et al (2013) who find that non-local passengers are overcharged by taxi

\footnotetext{
${ }^{29}$ To address Heckman criticism, Neumark (2012) focuses on a labour market application, and proposes a method to recover an unbiased estimate for job market discrimination, which exploits the variations of applicants' CV characteristics (i.e. education level). We cannot implement his proposed method for the following reasons. First, our identification strategy is a difference-in-differences method, while Neumark's method utilises two-group comparison without time dimension. Second, we did not design our experiment to included variation on buyers' characteristics aside from the football shirt.
} 
drivers.

However, this observation alone does not tell whether some of this discrimination is due to in-group and out-group preferences or rational profit maximization. We go beyond by introducing national shirt treatments and making within-buyer comparison to identify the presence of group biases in the market. Although nonBrazilians were overcharged, we did not find evidence of out-group bias in the bargaining outcomes, despite the high nationalistic moods triggered by the World Cup. The fact that buyers were wearing a shirt of Brazil' rival team one day before the game, could be taken as an insult, and could inspire some reciprocation in the form of higher prices or a lower likelihood of transaction. The absence of such a discrimination is in line with the view that the marketplace is free of emotions, and that possible impacts of personal preferences vanish under competition. This supports the Beckerian view that market competition does a remarkable job of eliminating bias. Recall that the markets that we study are highly competitive, and the products that our experimenters enquired for were available in many stores.

On the other hand, we find that the Brazil shirt was instrumental in determining bargaining outcomes when Brazil had won a match. We argue that the motive behind the favouritism was sellers' preference toward in-group buyers, which was primed by both the shirt and the victory. An alternative explanation for this finding (that we explore in Table A5 in the Appendix) is that instead, this favouritism was driven by some sort of "winner charm". The data rejects such explanation. ${ }^{30}$ The effects of in-group preferences in economic interactions have been detected in many

\footnotetext{
${ }^{30}$ More precisely, sellers might treat the supporters of a winning team better because they wanted to identify themselves with the successful group to enjoy the feeling of winning or because they believed that supporters of a victorious team are tougher negotiators. To examine this possibility, we looked at the case of Chile which defeated Australia on 13 June. One day before the game, Brazil won the match against Croatia. Experimenters visited the market on 14 June wearing Brazil and Chile shirts. If by that date, buyers wearing the shirt of the winning Chilean football team were treated better than usual, that would suggest that winner favouritism may be another plausible explanation for the pattern found in Table 3 than in-group favouritism. The results reported in Table A5 demonstrate that this is not the case. In fact, we find that sellers discriminated against the "Chilean winning shirt". That could be motivated by envy towards another successful group.
} 
settings such as donations, judicial choices, and monetary transfer in the field and in the lab, making people more collaborative and generous toward those "from the same group". To our knowledge, this paper provides the first evidence that in-group biases are also present in the real market. In fact, we detect relevant effects - with discounts of 10-12 percent on the second price and an increase of 33.5 percent in the likelihood of sellers' accepting the (settled) price. It is noteworthy that our setting provides strong evidence for the existence of in-group bias from the supply side, given that these sellers are mostly self-employed, work for small profit margins and supposedly cannot afford losses.

This research contributes to a large body of research on discrimination. (see Bertrand and Duflo 2017, Rich 2014 for reviews). Many previous works have focused on racial and gender biases, with evidence indicating that females, non-whites, foreigners, or other minorities are discriminated against in the labour market, rentals or product markets. Although, some of the findings might be driven by sexism or racism, these groups are also minorities, and might be perceived as out-groups. To our knowledge, there is still scarce investigation for the role of the "out-group" status in explaining gender and race discrimination. Our experiment was designed to isolate "in-group" and "out-group" (taste-based) discrimination, but focusing on a personal characteristic that is more easily disguised than gender or race. We manipulated experimenters' team preference - revealing antagonism or agreement with local sellers. In real life, individuals might anticipate the possibility of discrimination or favouritism, and self-select to interact with others with similar view, or hide their preferences when convenient. Our buyers were forced to sometimes reveal their team preferences. Even in this case, which could potentially lead to more hostility, we detected evidence of in-group favouritism, but no out-group discrimination.

Our final remark relates to the external validity of this study. Although the WC provided a nice opportunity to identify in-group and out-group biases, the mental state during the WC ("hot state") might differ substantially from that in everyday life, when people might feel less nationalistic; however, there are many important situations that are similar to our experimental environment. For example, during election time, people support causes, take sides, and often express their opinions 
through the clothes they wear. In such a case, the expressed political preference of buyers may lead them be treated differentially in the market.

\section{References}

[1] Akerlof, G. A. and R. E. Kranton. 2010. Identity Economics, Princeton University Press.

[2] Ayres, I., M. Banaji, and C. Jolls. 2015. "Race effects on eBay," RAND Journal of Economics 46(4): 891-917.

[3] Ball, S., C. Eckel, P. Grossman, and W. Zame, 2001. "Status in markets". Quarterly Journal of Economics 155 (1): 61-181.

[4] Bargh, J. A. 2014. "The Historical Origins of Priming as the Preparation of Behavioral Responses: Unconscious Carryover and Contextual Influences of Real-World Importance." Social Cognition 32, Understanding Priming Effects in Social Psychology, 209-224.

[5] Becker, G., 1971. The Economics of Discrimination, 2nd ed. University of Chicago Press.

[6] Balafoutas, L., B. Adrian, R. Kerschbamer and M. Sutter. 2013. "What Drives Taxi Drivers? A Field Experiment on Fraud in a Market for Credence Goods" Review of Economic Studies 80: 876-891.

[7] Benabou, R. and J. Tirole .2011. "Identity, Morals, and Taboos: Beliefs as Assets." Quarterly Journal of Economics 126: 805-855.

[8] Benjamin, D. J., J. Choi, and A. J. Strickland. 2010. "Social Identity and Preferences." American Economic Review, 100(4): 1913-28.

[9] Bertrand M. and E. Duflo. 2017. "Field Experiments on Discrimination", in Handbook of Field Experiments, Volume 1, Edited by Abhijit Vinayak Banerjee, Esther Duflo.

[10] Bertrand, M., and S. Mullainathan. 2004. "Are Emily and Greg more employable than Lakisha and Jamal? A feild experiment on labor market 
discrimination." American Economic Review, 94(4): 991-1013.

[11] Bizman, A., and Y. Yinon. 2002. "Engaging in distancing tactics among sport fans: Effects on self-esteem and emotional responses." Journal of Social Psychology 142: 381-392.

[12] Card, D., A. Mas, E. Moretti, and E. Saez. 2012. "Inequality at Work: The Effect of Peer Salaries on Job Satisfaction." American Economic Review, 102(6): 2981-3003.

[13] Castillo, M., R. Petrie, M. Torero and L. Vesterlund .2013. "Gender Differences in Bargaining Outcomes: A Field Experiment on Discrimination." Journal of Public Economics 99: 35-48.

[14] Chen Y, S. X. Li, T. X. Liu, M. Shih. 2014. "Which hat to wear? Impact of natural identities on coordination and cooperation." Games and Economic Behavior 84: 58-86

[15] Chen, Y. and S. X. Li. 2009. "Group Identity and Social Preferences." American Economic Review, 99(1): 431-57.

[16] Cialdini, R. B., R. J. Borden, A. Thorne, M. R. Walker, S. Freeman, and L. R. Sloan. 1976. Basking in reflected glory: Three (football) field studies. Journal of Personality and Social Psychology, 34: 366-375.

[17] Crocker, J. and R. Luhtanen. 1990. "Collective self-esteem and ingroup bias.", Journal of Personality and Social Psychology, 58(1): 60-67.

[18] Doleac, J. L. and L. C. Stein. 2013. "The visible hand: Race and online market outcomes," Eonomic Journal, 123: 469-92.

[19] Eckel, C. and P. Grossman. 2005. "Managing Diversity by Creating Team Identity." Journal of Economic Behavior and Organization, 58(3): 371-392.

[20] Edmans, A., D. Garcia. and Ø Norli. 2007. "Sports Sentiment and Stock Returns." The Journal of Finance, 62: 1967-1998.

[21] Esses, V.. G. Haddock and M. Zanna. 1993. Values, Stereotypes, and Emotions as Determinants of intergroup Attitudes. In Mackie, Diane M. (Ed); Hamilton, David Lewis (Ed), (29.93). Affect, cognition, and stereotyping: 
Interactive processes in group perception. , (pp. 137-163). San Diego, CA, US: Academic Press.

[22] Ewens, M., B. Tomlin. and L-C. Wang. 2014. "Statistical discrimination or prejudice? A large sample field experiment," Review of Economics and Statistics, 96 (1): 119-134.

[23] Fong, C.M., and E. F. P. Luttmer. 2009. "What Determines Giving to Hurricane Katrina Victims? Experimental Evidence on Racial Group Loyalty." American Economic Journal: Applied Economics, 1(2): 64-87.

[24] Gneezy, U., J. List and M. Price. 2012. "toward an understanding of why people discriminate: evidence from a series of natural field experiments." NBER Working Paper No. 17855.

[25] Goette, L., D. Huffman, and S. Meier. 2006. "The Impact of Group Membership on Cooperation and Norm Enforcement: Evidence Using Random Assignment to Real Social Groups." American Economic Review, 96(2): 212-216.

[26] Guryan, J. and Charles, K. K. 2013. "Taste-based or Statistical Discrimination: The Economics of Discrimination Returns to its Roots." The Economic Journal, 123: 417-432.

[27] Hassin, R. R., M. J. Ferguson, D. Shidlovski and L. Gross. 2007. "Subliminal exposure to national flags affects political thought and behavior." Proceedings of the National Academy of Sciences, USA, 104: 19757-19761.

[28] Heckman, J. J. 1998. "Detecting discrimination," Journal of Economic Perspectives, 12(2): 101-16.

[29] Heckman, J. J. and P. Siegelman. 1993. "The unban institute audit studies: Their methods and findings." In Clear and Convincing Evidence: Measurement of Discrimination in America. ed. Fix and Struyk, 187-258. Washington D.C., The Urban Institute Press.

[30] Ifcher, J. and H. Zarghamee. 2011. "Happiness and Time Preference: The effect of Positive Affect in a Random-Assignment Experiment," American 
Economic Review, 101(4): 3109-3129.

[31] Jones, M. V., P. Coffee, D. Sheffield, M. Yanguez and J. B. Barker 2012. "Just a game? Changes in English and Spanish soccer fans' emotions in the 2010 World Cup," Psychology of Sport and Exercise 13, 162-169.

[32] Li, S.X., Dogan, K. and E. Haruvy 2011. "Group identity in markets." International Journal of Industrial Organization 29: 104-115.

[33] List, J.A. 2004. "The nature and extent of discrimination in the marketplace: evidence from the field." Quarterly Journal of Economics 119(1): 49-89.

[34] Molden. D. C. 2014. "Understanding Priming Effects in Social Psychology: What is "Social Priming" and How does it Occur?" Social Cognition 32, Understanding Priming Effects in Social Psychology, 1-11.

[35] Morita, H. and M. Servátka. 2013. "Group Identity and Relation-Specific Investment: An Experimental Investigation," European Economic Review, 58(2): 95-109.

[36] Neumark, D. 1996. "Sex discrimination in restaurant hiring: An audit study." Quarterly Journal of Economics, 111(3): 915-41.

[37] Neumark, D. 2012. "Detecting discrimination in audit and correspondence studies." Journal of Human Resources, 47(4): 1128-55.

[38] "World Cup Survival Guide", New York Times 12/6/2014, http://www.nytimes.com/2014/06/13/opinion/cohenworld-cup-survival-guide.html?_r=0

[39] "Making Holidays of Brazil's World Cup Games," New York Times 9/6/2014, http://www.nytimes.com/2014/06/10/sports/worldcup/makingholidays-of-brazil-world-cup-games.html

[40] Oreopoulos, P. 2011. "Why Do Skilled Immigrants Struggle in the Labor Market? A Field Experiment with Thirteen Thousand Resumes." American Economic Journal: Economic Policy, 3(4): 148-71.

[41] Perdue, C. W., J. F. Dovidio, M. B. Gurtman, and R. B. Tyler. 1990. "Us and them: Social categorization and the process of ingroup bias," Journal of 
Personality and Social Psychology, 59: 475-486.

[42] Phelps, E., 1972. "The statistical theory of racism and sexism." American Economic Review 62: 659-661.

[43] Platow, M. J., M. Durante, N. Williams, M. Garrett, J. Walshe, S. Cincotta, G. Lianos, and A. Barutchu 1999. "The contribution of sport fan social identity to the production of prosocial behavior." Group Dynamics: Theory, Research, and Practice, 3(2): 161-169.

[44] Rich, J., 2014 "What Do Field Experiments of Discrimination in Markets Tell Us? A Meta Analysis of Studies Conducted Since 2000." IZA Discussion Paper No. 8584.

[45] Rick, S. and G. Loewenstein. 2008. "The Role of Emotion in Economic Behavior," in Lewis, M., Haviland-Jones, J. M., \& Barrett, L. F. (Eds.). Handbook of Emotions, 3rd Edition. New York: Guilford.

[46] Sen, A. 2007. Identity and violence: The illusion of destiny. New York: W. W. Norton \& Company.

[47] Shayo, M. and A. Zussman. 2010. "Judicial In-group Bias in the Shadow of. Terrorism." Quarterly Journal of Economics. 126: 1147-1484

[48] Shih, M., T. L. Pittinsky, A. Trahan and N. Ambady. 1999. "Stereotype Susceptibility: Identity Salience and Shifts in Quantitative Performance," Psychological Science, 10 (1): 81-84.

[49] Wann, D. L and F.rederick G Grieve. 2005. "Biased Evaluations of In-Group and Out-Group Spectator Behavior at Sporting Events: The Importance of Team Identification and Threats to Social Identity," The Journal of Social Psychology, 145 (5): 531-546.

[50] Wann, D. L., M. J. Melnick, G. W. Russell and D. G. Pease. 2001. Sport fans: The psychology and social impact of spectators. New York: Routledge.

[51] Wilder, D. and P. Shapiro. 1989. "Role of competition-induced anxiety in limiting the beneficial impact of positive behavior by an out-group member." Journal of Personality and Social Psychology, 56(1)-60-69. 
[52] Zussman, A. 2013. "Ethnic Discrimination: Lessons from the Israeli Online Market for Used Cars." The Economic Journal, 123:433-468. 


\section{Figure 1 - Timeline}

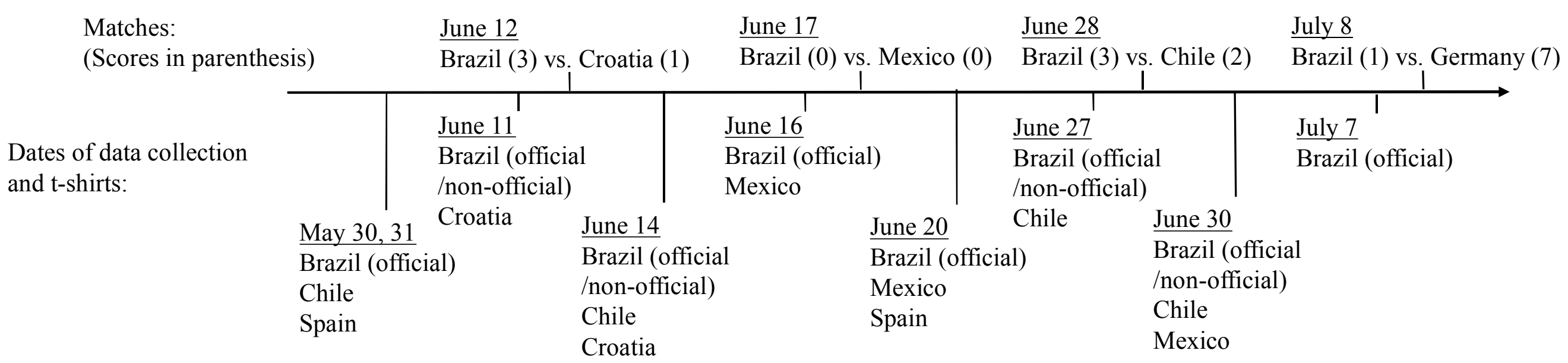


Table 1. Number of Interactions by Market, Nationality and Treatment Mercado Santa Efiginia Mercado Paulista Total

\begin{tabular}{lccc}
\hline \hline Brazilian Pair & 373 & 95 & $468(51 \%)$ \\
Jacket & 145 & 43 & $188(20.5 \%)$ \\
Brazil Shirt & 228 & 52 & $280(30.5 \%)$ \\
$\quad$ Official Shirt & 151 & 43 & $194(21.1 \%)$ \\
$\quad$ Non-official Shirt & 77 & 9 & $86(9.4 \%)$ \\
& & & \\
Non-Brazilian Pair & 311 & 139 & $450(49 \%)$ \\
Jacket & 137 & 66 & $203(22.1 \%)$ \\
National Official Shirt & 174 & 73 & $247(26.9 \%)$ \\
$\quad$ Chile & 76 & 12 & $88(9.5 \%)$ \\
$\quad$ Croatia & 25 & 22 & $47(5.1 \%)$ \\
$\quad$ Mexico & 51 & 18 & $69(7.5 \%)$ \\
$\quad$ Spain & 22 & 21 & $43(4.7 \%)$ \\
\hline Total & $684(74.5 \%)$ & $234(25.5 \%)$ & 918 \\
\hline \hline
\end{tabular}


Table 2. Effect of Being a Brazilian Buyer

\begin{tabular}{|c|c|c|c|c|c|}
\hline & (1) & (2) & (3) & $\mathrm{N}$ & Sample \\
\hline $\begin{array}{l}\text { Dependent variable: } \\
\ln (\text { First price })\end{array}$ & $\begin{array}{c}-0.0678 \\
(0.0189)^{* *}\end{array}$ & $\begin{array}{c}-0.0622 \\
(0.0192)^{* *}\end{array}$ & $\begin{array}{c}-0.0632 \\
(0.0144)^{* *}\end{array}$ & 698 & All \\
\hline $\ln$ (Second price) & $\begin{array}{c}-0.0549 \\
(0.0229)^{* *}\end{array}$ & $\begin{array}{c}-0.0532 \\
(0.0276)^{*}\end{array}$ & $\begin{array}{c}-0.0540 \\
(0.0230)^{* *}\end{array}$ & 554 & All \\
\hline Accepted Offer & $\begin{array}{r}0.0478 \\
(0.0342) \\
\end{array}$ & $\begin{array}{r}0.0401 \\
(0.0271) \\
\end{array}$ & $\begin{array}{r}0.0401 \\
(0.0309) \\
\end{array}$ & 698 & All \\
\hline Product fixed-effects & Yes & Yes & Yes & & \\
\hline $\begin{array}{l}\text { Day and time of visit } \\
\text { and street fixed effects }\end{array}$ & No & Yes & Yes & & \\
\hline Buyer-pair random effects & No & No & Yes & & \\
\hline
\end{tabular}

Note: Robust standard errors are in parenthesis.

* Significant at the $10 \%$ level, ** Significant at the 5\% level. 
Table 3. Testing the Ingroup Bias hypothesis

\begin{tabular}{lcccccc}
\hline \hline Dependent variable: & \multicolumn{2}{c}{$\ln ($ First Price $)$} & \multicolumn{2}{c}{$\ln ($ Second Price) } & \multicolumn{2}{c}{ Accepted Offer } \\
& $(1)$ & $(2)$ & $(3)$ & $(4)$ & $(5)$ & $(6)$ \\
\hline Brazil Shirt $\times$ Victory & -0.0252 & & -0.1129 & & 0.3354 & \\
& $(0.0226)$ & & $(0.0396)^{* *}$ & & $(0.1083)^{* *}$ \\
& & & & & & \\
& & -0.0235 & & -0.1074 & & 0.2459 \\
Official Shirt x Victory & & $(0.0275)$ & & $(0.0401)^{* *}$ & $(0.1403)$ \\
& & -0.0223 & & -0.0915 & \\
Unofficial Shirt x Victory & & $(0.0342)$ & & $(0.0498)^{*}$ & \\
& & & & & & 0.5103 \\
Sample & Brazilian & Brazilian & Brazilian & Brazilian & Brazilian & Brazilian \\
\hline
\end{tabular}

Note: Each entry is the estimate of $\pi 2, \varphi 3$ or $\varphi 4$. All specifications include buyer-pair, product and street fixed effects and indicators for day and time of visit. Robust standard errors clustered at the store address level are in parenthesis. *

Significant at the $10 \%$ level, ** Significant at the $5 \%$ level. 
Table 4. Testing the Outgroup Bias hypothesis

\begin{tabular}{|c|c|c|c|c|c|c|c|c|}
\hline \multirow[t]{2}{*}{ Dependent variable: } & \multicolumn{2}{|c|}{$\ln$ (First Price) } & \multicolumn{2}{|c|}{$\ln$ (Second Price) } & \multicolumn{2}{|c|}{ Accepted Offer } & \multicolumn{2}{|c|}{ Did not help on directions } \\
\hline & (1) & (2) & (3) & (4) & (5) & (6) & (7) & $(8)$ \\
\hline non-Brazil Shirt $\times$ Rival & $\begin{array}{l}-0.0183 \\
(0.0434)\end{array}$ & & $\begin{array}{l}-0.0026 \\
(0.0625)\end{array}$ & & $\begin{array}{c}0.2040 \\
(0.1845)\end{array}$ & & $\begin{array}{c}0.2258 \\
(0.1389)\end{array}$ & \\
\hline non-Brazil Shirt $\times$ Defeated & & $\begin{array}{l}-0.0120 \\
(0.0366)\end{array}$ & & $\begin{array}{c}0.0162 \\
(0.0358)\end{array}$ & & $\begin{array}{l}-0.0710 \\
(0.1570)\end{array}$ & & $\begin{array}{l}-0.2216 \\
(0.2303)\end{array}$ \\
\hline Sample & $\begin{array}{l}\text { non- } \\
\text { Brazilian }\end{array}$ & $\begin{array}{l}\text { non- } \\
\text { Brazilian }\end{array}$ & $\begin{array}{l}\text { non- } \\
\text { Brazilian }\end{array}$ & $\begin{array}{l}\text { non- } \\
\text { Brazilian }\end{array}$ & $\begin{array}{l}\text { non- } \\
\text { Brazilian }\end{array}$ & $\begin{array}{l}\text { non- } \\
\text { Brazilian }\end{array}$ & $\begin{array}{l}\text { non- } \\
\text { Brazilian }\end{array}$ & $\begin{array}{l}\text { non- } \\
\text { Brazilian }\end{array}$ \\
\hline Num. of Obs. & 333 & 333 & 276 & 276 & 333 & 333 & 106 & 106 \\
\hline
\end{tabular}


Table A1- Robustness Check

\begin{tabular}{|c|c|c|c|c|c|}
\hline \multirow[t]{2}{*}{ Dependent variable: } & \multicolumn{5}{|c|}{$\begin{array}{l}\text { Friend' Buyer Assessment on Buyers' Confidence in his/her interaction } \\
\text { with Seller }\end{array}$} \\
\hline & (1) & (2) & (3) & (4) & (5) \\
\hline \multirow[t]{2}{*}{ Shirt $\times$ Victory } & -0.2412 & 0.0469 & & & 0.0750 \\
\hline & $(0.1586)$ & $(0.2409)$ & & & $(0.2283)$ \\
\hline \multirow[t]{2}{*}{ Shirt $\times$ Rival } & & & 0.0395 & & 0.0665 \\
\hline & & & $(0.1115)$ & & $(0.1186)$ \\
\hline \multirow[t]{2}{*}{ Shirt $\times$ Defeated } & & & & 0.0001 & 0.0362 \\
\hline & & & & $(0.0731)$ & $(0.0785)$ \\
\hline \multicolumn{6}{|l|}{ Shirt } \\
\hline \multirow[t]{2}{*}{ Brazil (Official) } & -0.0480 & & & & \\
\hline & $(0.0486)$ & & & & \\
\hline \multirow[t]{2}{*}{ Brazil (Unofficial) } & -0.0375 & & & & \\
\hline & $(0.0749)$ & & & & \\
\hline \multirow[t]{2}{*}{ Chile } & & 0.0261 & 0.0256 & 0.0371 & -0.0053 \\
\hline & & $(0.0750)$ & $(0.0971)$ & $(0.0790)$ & $(0.0921)$ \\
\hline \multirow[t]{2}{*}{ Croatia } & & 0.0117 & -0.0112 & 0.0096 & -0.0383 \\
\hline & & $(0.0622)$ & $(0.0610)$ & $(0.0799)$ & $(0.0868)$ \\
\hline \multirow[t]{2}{*}{ Mexico } & & 0.0528 & 0.0354 & 0.0541 & 0.0137 \\
\hline & & $(0.0672)$ & $(0.0873)$ & $(0.0590)$ & $(0.0816)$ \\
\hline \multirow[t]{2}{*}{ Spain } & & -0.2595 & -0.2592 & -0.2578 & -0.2843 \\
\hline & & $(0.0669)^{* *}$ & $(0.0678)^{* *}$ & $(0.0654)^{* *}$ & $(0.0655)^{* *}$ \\
\hline Sample (pair) & Brazilian & non-Brazilian & non-Brazilian & non-Brazilian & on-Brazilian \\
\hline Num. of Obs. & 467 & 439 & 439 & 439 & 439 \\
\hline
\end{tabular}

Note: The dependent variable is the buyer' friend perception on how the buyer felt/behaved during the interaction with the sellers, in a scale 1 to 5 , where 1 correspond to very uncomfortable and 5 relates to very comfortable. The question was "How confortable your partner seemed during the negotiation?" All specifications include buyer-pair fixed effects, indicators for product, day, time of the store visit and stores' addresses. Robust standard errors clustered at the store address level are in parenthesis.

** Significant at the $5 \%$ level. 
Table A2- Randomization Check: Effects of Shirts on stores and enquired product

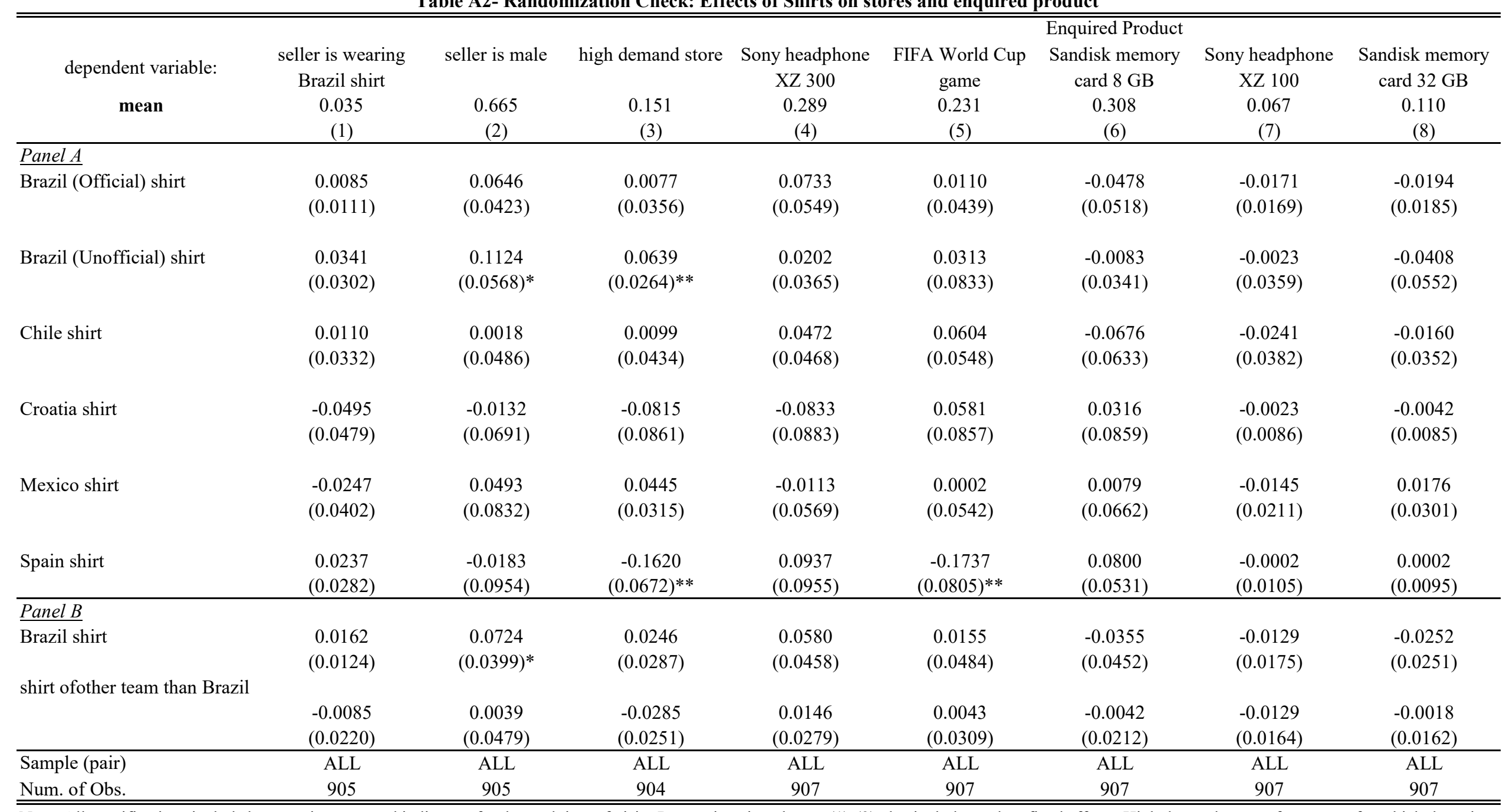

Note: All specifications include buyer-pair, street and indicators for day and time of visit. Regressions in columns (1)-(3) also include product fixed effects. High demand store refer to store for which the pair had to wait to be attended because there were other customers in the store. Robust standard errors clustered at the store address level are in parenthesis.

* Significant at the $10 \%$ level, ** Significant at the $5 \%$ level. 
Table A3. The full results of the main regressions

\begin{tabular}{|c|c|c|c|c|c|c|}
\hline \multicolumn{7}{|c|}{ Panel A. In-group bias } \\
\hline & \multicolumn{2}{|c|}{$\log ($ First Price $)$} & \multicolumn{2}{|c|}{$\log ($ Second Price $)$} & \multicolumn{2}{|c|}{ Accepted Offer } \\
\hline & $(1)$ & $(2)$ & $(3)$ & (4) & $(5)$ & $(6)$ \\
\hline \multicolumn{7}{|c|}{ Brazil Shirt $\times$ Victory } \\
\hline Any & $\begin{array}{l}-0.0252 \\
(0.0226)\end{array}$ & & $\begin{array}{c}-0.1129 * * \\
(0.0396)\end{array}$ & & $\begin{array}{c}0.3354 * * \\
(0.1083)\end{array}$ & \\
\hline Official Shirt & & $\begin{array}{l}-0.0235 \\
(0.0275)\end{array}$ & & $\begin{array}{c}-0.1074 * * \\
(0.0401)\end{array}$ & & $\begin{array}{c}0.2459 \\
(0.1403)\end{array}$ \\
\hline Unofficial Shirt & & $\begin{array}{l}-0.0223 \\
(0.0342)\end{array}$ & & $\begin{array}{c}-0.0915^{*} \\
(0.0498)\end{array}$ & & $\begin{array}{c}0.5103 * * \\
(0.0993)\end{array}$ \\
\hline \multicolumn{7}{|l|}{ Brazil Shirt } \\
\hline Any & $\begin{array}{c}0.0202 \\
(0.0117)\end{array}$ & & $\begin{array}{c}0.0548 \\
(0.0377)\end{array}$ & & $\begin{array}{c}-0.1029 * * \\
(0.0432)\end{array}$ & \\
\hline Official Shirt & & $\begin{array}{c}0.0235 \\
(0.0179)\end{array}$ & & $\begin{array}{l}0.0681 * \\
(0.0381)\end{array}$ & & $\begin{array}{l}-0.0699 \\
(0.0432)\end{array}$ \\
\hline Non-official Shirt & & $\begin{array}{r}0.0098 \\
(0.039) \\
\end{array}$ & & $\begin{array}{c}0.0040 \\
(0.0605) \\
\end{array}$ & & $\begin{array}{c}-0.2078 * * \\
(0.0622)\end{array}$ \\
\hline Sample (pair) & Brazilian & Brazilian & Brazilian & Brazilian & Brazilian & Brazilian \\
\hline Num. of Obs. & & 63 & & 76 & & \\
\hline \multicolumn{7}{|c|}{ Panel B. Out-group bias } \\
\hline & \multicolumn{2}{|c|}{$\log$ (First Price) } & \multicolumn{2}{|c|}{$\log ($ Second Price $)$} & \multicolumn{2}{|c|}{ Accepted Offer } \\
\hline & (1) & $(2)$ & (3) & (4) & (5) & (6) \\
\hline Shirt $\times$ Rivalry & $\begin{array}{c}-0.0183 \\
(0.0434)\end{array}$ & & $\begin{array}{c}-0.0027 \\
(0.0625)\end{array}$ & & $\begin{array}{c}0.2040 \\
(0.1845)\end{array}$ & \\
\hline Shirt $\times$ Defeat & & $\begin{array}{l}-0.0120 \\
(0.0366)\end{array}$ & & $\begin{array}{c}0.0162 \\
(0.0358)\end{array}$ & & $\begin{array}{l}-0.0710 \\
(0.1570)\end{array}$ \\
\hline \multicolumn{7}{|l|}{ Shirt } \\
\hline Chile & $\begin{array}{l}-0.0517 \\
(0.0488)\end{array}$ & $\begin{array}{l}-0.0527 \\
(0.0435)\end{array}$ & $\begin{array}{l}-0.0481 \\
(0.0703)\end{array}$ & $\begin{array}{l}-0.0537 \\
(0.0537)\end{array}$ & $\begin{array}{c}-0.0061 \\
(0.1413)\end{array}$ & $\begin{array}{c}0.0648 \\
(0.1507)\end{array}$ \\
\hline Croatia & $\begin{array}{c}0.0434 \\
(0.0568)\end{array}$ & $\begin{array}{c}0.0377 \\
(0.0566)\end{array}$ & $\begin{array}{c}0.0525 \\
(0.0433)\end{array}$ & $\begin{array}{c}0.0438 \\
(0.0396)\end{array}$ & $\begin{array}{l}-0.2385 \\
(0.1825)\end{array}$ & $\begin{array}{l}-0.0914 \\
(0.1545)\end{array}$ \\
\hline Mexico & $\begin{array}{l}-0.0172 \\
(0.0335)\end{array}$ & $\begin{array}{l}-0.0241 \\
(0.0307)\end{array}$ & $\begin{array}{l}-0.0415 \\
(0.0534)\end{array}$ & $\begin{array}{l}-0.0462 \\
(0.0415)\end{array}$ & $\begin{array}{c}0.0504 \\
(0.1499)\end{array}$ & $\begin{array}{l}0.1598 * \\
(0.0879)\end{array}$ \\
\hline Spain & $\begin{array}{c}0.0532 \\
(0.0298)\end{array}$ & $\begin{array}{c}0.0605 \\
(0.0414)\end{array}$ & $\begin{array}{c}0.0226 \\
(0.0420)\end{array}$ & $\begin{array}{c}0.0118 \\
(0.0455)\end{array}$ & $\begin{array}{l}-0.0029 \\
(0.0806)\end{array}$ & $\begin{array}{c}0.0512 \\
(0.1522)\end{array}$ \\
\hline
\end{tabular}

Sample Non-Brazilian Non-Brazilian Non-Brazilian Non-Brazilian Non-Brazilian Non-Brazilian

Num. of Obs. 333 276 333

Note: Robust standard errors clustered at the store address level are in parenthesis. * Significant at the 10\% level, ** Significant at the 5\% level. 
Table A4. Effect of Team Shirt on Market Outcomes

\begin{tabular}{|c|c|c|c|c|c|c|c|c|c|}
\hline \multirow[t]{2}{*}{ dependent variable: } & \multicolumn{2}{|c|}{ First Price } & \multicolumn{3}{|c|}{ "Second Price } & \multicolumn{4}{|c|}{ "Accepted Offer } \\
\hline & (1) & (2) & (3) & (4) & $(5)$ & $(6)$ & (7) & (8) & (9) \\
\hline Brazil Shirt $\times$ Victory & $\begin{array}{l}-0.0197 \\
(0.0271)\end{array}$ & $\begin{array}{l}-0.0225 \\
(0.0267)\end{array}$ & $\begin{array}{l}-0.0205 \\
(0.0262)\end{array}$ & $\begin{array}{c}-0.1034 \\
(0.0312)^{* *}\end{array}$ & $\begin{array}{c}-0.1062 \\
(0.0315)^{*}\end{array}$ & $\begin{array}{c}-0.1046 \\
(0.0317)^{* *}\end{array}$ & $\begin{array}{c}0.2588 \\
(0.1190)^{*}\end{array}$ & $\begin{array}{c}0.2678 \\
(0.1184)^{* *}\end{array}$ & $\begin{array}{c}0.2575 \\
(0.1305)^{*}\end{array}$ \\
\hline Chile Shirt $\times$ Victory & & $\begin{array}{c}0.1440 \\
(0.0597)^{* *}\end{array}$ & $\begin{array}{c}0.1655 \\
(0.0757)^{* *}\end{array}$ & & $\begin{array}{c}0.1619 \\
(0.0895)^{*}\end{array}$ & $\begin{array}{c}0.2248 \\
(0.0906)^{* *}\end{array}$ & & $\begin{array}{c}-0.4466 \\
(0.1396)^{* *}\end{array}$ & $\begin{array}{c}-0.4610 \\
(0.1109)^{* *}\end{array}$ \\
\hline non-Brazil Shirt $\times$ Rival & & & $\begin{array}{c}0.0187 \\
(0.0621)\end{array}$ & & & $\begin{array}{c}0.0909 \\
(0.0828)\end{array}$ & & & $\begin{array}{c}0.0648 \\
(0.1708)\end{array}$ \\
\hline non-Brazil Shirt $\times$ Defeated & & & $\begin{array}{c}0.0365 \\
(0.0546)\end{array}$ & & & $\begin{array}{c}0.0981 \\
(0.0625)\end{array}$ & & & $\begin{array}{l}-0.0570 \\
(0.1448)\end{array}$ \\
\hline Brazil shirt & $\begin{array}{c}0.0089 \\
(0.0118)\end{array}$ & $\begin{array}{c}0.0104 \\
(0.0119)\end{array}$ & $\begin{array}{c}0.0098 \\
(0.0119)\end{array}$ & $\begin{array}{c}0.0489 \\
(0.0298)\end{array}$ & $\begin{array}{c}0.0513 \\
(0.0300)\end{array}$ & $\begin{array}{c}0.0501 \\
(0.0303)\end{array}$ & $\begin{array}{c}-0.0871 \\
(0.0460)^{*}\end{array}$ & $\begin{array}{c}-0.0920 \\
(0.0454)^{* *}\end{array}$ & $\begin{array}{c}-0.0888 \\
(0.0462)^{*}\end{array}$ \\
\hline Chile shirt & $\begin{array}{c}-0.0737 \\
(0.0387)^{*}\end{array}$ & $\begin{array}{c}-0.1078 \\
(0.0514)^{* *}\end{array}$ & $\begin{array}{c}-0.1288 \\
(0.0690)^{*}\end{array}$ & $\begin{array}{l}-0.0646 \\
(0.0535)\end{array}$ & $\begin{array}{l}-0.0957 \\
(0.0721)\end{array}$ & $\begin{array}{c}-0.1618 \\
(0.0874)^{*}\end{array}$ & $\begin{array}{c}0.0895 \\
(0.1111)\end{array}$ & $\begin{array}{c}0.1955 \\
(0.1087)^{*}\end{array}$ & $\begin{array}{c}0.2016 \\
(0.1149)\end{array}$ \\
\hline Croatia shirt & $\begin{array}{l}0.04219 \\
(0.0565)\end{array}$ & $\begin{array}{c}0.0461 \\
(0.0566)\end{array}$ & $\begin{array}{c}0.0209 \\
(0.0595)\end{array}$ & $\begin{array}{c}0.0192 \\
(0.0405)\end{array}$ & $\begin{array}{c}0.0250 \\
(0.0400)\end{array}$ & $\begin{array}{l}-0.0682 \\
(0.0589)\end{array}$ & $\begin{array}{l}-0.1221 \\
(0.1076)\end{array}$ & $\begin{array}{l}-0.1344 \\
(0.1068)\end{array}$ & $\begin{array}{l}-0.1504 \\
(0.1871)\end{array}$ \\
\hline Mexico shirt & $\begin{array}{l}-0.0321 \\
(0.0307)\end{array}$ & $\begin{array}{l}-0.0352 \\
(0.0311)\end{array}$ & $\begin{array}{l}-0.0512 \\
(0.0444)\end{array}$ & $\begin{array}{l}-0.0668 \\
(0.0540)\end{array}$ & $\begin{array}{l}-0.0702 \\
(0.0553)\end{array}$ & $\begin{array}{c}-0.1375 \\
(0.0551)^{* *}\end{array}$ & $\begin{array}{c}0.1385 \\
(0.0751)^{*}\end{array}$ & $\begin{array}{c}0.1482 \\
(0.0736)^{* *}\end{array}$ & $\begin{array}{c}0.1287 \\
(0.1221)\end{array}$ \\
\hline Spain shirt & $\begin{array}{c}0.0882 \\
(0.0251)^{* *}\end{array}$ & $\begin{array}{c}0.0854 \\
(0.0242)^{* *}\end{array}$ & $\begin{array}{c}0.0581 \\
(0.0537)\end{array}$ & $\begin{array}{c}0.0482 \\
(0.0358) \\
\end{array}$ & $\begin{array}{c}0.0447 \\
(0.0350)\end{array}$ & $\begin{array}{l}-0.0322 \\
(0.0666)\end{array}$ & $\begin{array}{l}-0.0769 \\
(0.0846)\end{array}$ & $\begin{array}{l}-0.0681 \\
(0.0836) \\
\end{array}$ & $\begin{array}{l}-0.0311 \\
(0.1526)\end{array}$ \\
\hline Sample (pair) & All & All & All & All & All & All & All & All & All \\
\hline Num. of Obs. & 696 & 696 & 696 & 552 & 552 & 552 & 696 & 696 & 696 \\
\hline
\end{tabular}

Note: All specifications include buyer-pair, product and street fixed effects and indicators for day and time of visit . Robust standard errors clustered at the store address level are in parenthesis. * Significant at the $10 \%$ level, ** Significant at the $5 \%$ level. 
Table A5. Effect of the Winning Shirt

\begin{tabular}{|c|c|c|c|c|c|c|}
\hline \multirow[t]{2}{*}{ Dependent variable: } & \multicolumn{2}{|c|}{$\ln$ (First Price) } & \multicolumn{2}{|c|}{$\ln ($ Second Price $)$} & \multicolumn{2}{|c|}{ Accepted Offer } \\
\hline & $(1)$ & $(2)$ & (3) & $(4)$ & $(5)$ & $(6)$ \\
\hline Chile Shirt $\times$ Victory & $\begin{array}{l}0.2107^{* *} \\
(0.0708)\end{array}$ & & $\begin{array}{c}0.1900 \\
(0.1170)\end{array}$ & & $\begin{array}{c}-0.5590 * * \\
(0.2090)\end{array}$ & \\
\hline Brazil Shirt $\times$ Victory & & $\begin{array}{l}-0.0252 \\
(0.0226)\end{array}$ & & $\begin{array}{c}-0.1129 \\
(0.0396)^{* *}\end{array}$ & & $\begin{array}{c}0.3354 \\
(0.1083)^{* *}\end{array}$ \\
\hline Sample & $\begin{array}{l}\text { non- } \\
\text { Brazilian }\end{array}$ & Brazilian & $\begin{array}{l}\text { non- } \\
\text { Brazilian }\end{array}$ & Brazilian & $\begin{array}{l}\text { non- } \\
\text { Brazilian }\end{array}$ & Brazilian \\
\hline Num. of Obs. & 333 & 363 & 276 & 276 & 333 & 363 \\
\hline
\end{tabular}

Note: All specifications include buyer-pair, product and street fixed effects and indicators for day and time of visit. Robust standard errors clustered at the store address level are in parenthesis. * Significant at the $10 \%$ level, ** Significant at the $5 \%$ level. 


\section{Appendix - Enquired Products}
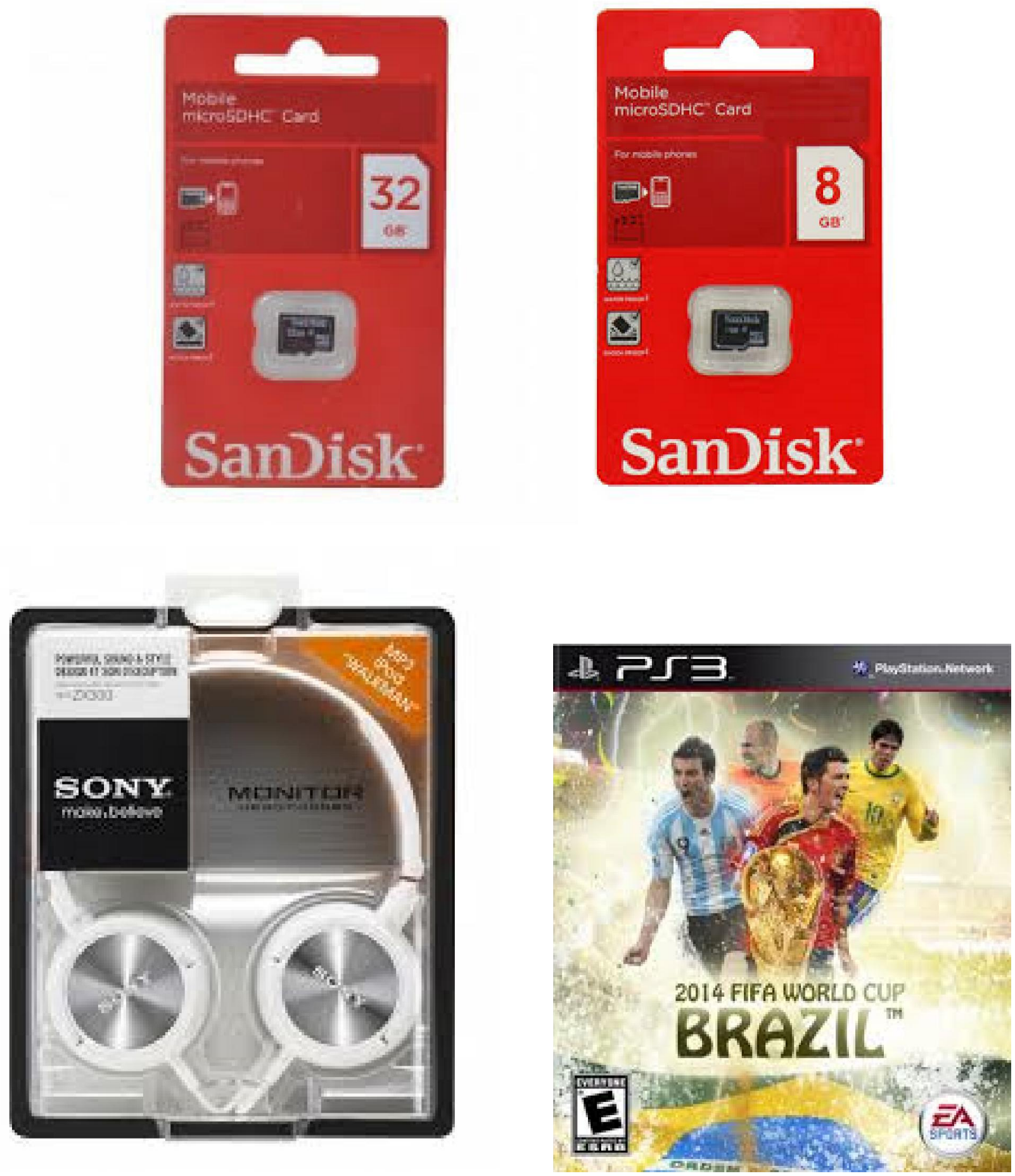
$\underline{\text { Results of Relevant Matches (shaded) }}$

\section{Group stage}

Group A

12 June

\begin{tabular}{|c|c|c|c|}
\hline & Brazil & $3-1$ & Croatia \\
\hline \multicolumn{4}{|l|}{17 June } \\
\hline & Brazil & $0-0$ & Mexico \\
\hline \multicolumn{4}{|l|}{23 June } \\
\hline & Brazil & $4-1$ & Cameroon \\
\hline & Mexico & $3-1$ & Croatia \\
\hline \multicolumn{4}{|l|}{13 June } \\
\hline & Mexico & $1-0$ & Cameroon \\
\hline \multicolumn{4}{|l|}{18 June } \\
\hline & Croatia & $4-0$ & Cameroon \\
\hline
\end{tabular}

\begin{tabular}{|lccc|}
\hline Group B & & & \\
\hline \hline 13 June & & & \\
& Netherlands & $5-1$ & Spain \\
& Chile & $3-1$ & Australia \\
18 June & Spain & $3-0$ & Australia \\
& Netherlands & $2-0$ & Chile \\
& Netherlands & $3-2$ & Australia \\
& Chile & $2-0$ & Spain \\
\hline
\end{tabular}

* The numbers in the parenthesis in Brazil vs. Chile match are the penalty shoot-outs.

\section{Semi final}

Quarter final 


\section{SCRIPT}

When the item was available:

Buyer: "Do you sell Sony headphones XZ300?"

Seller: Yes

Buyer: "How much does it cost, paying in cash?"

Seller: It costs 140 reais

Buyer: "Can you sell by 115 [maximum-acceptable] price?"

Seller: I can sell to you by 130

Buyer: "Can you sell by 115 price?"

Seller: Yes/No, I can sell you by $\mathbf{1 2 0}$

Buyer: "Can you sell by 115 price?"

Buyer: "Thank you. We will look around".

Buyer' Friend: "Do you have a card from here, so we can come back later?"

When the item was NOT available:

Buyer: "Do you sell product Sony headphone XZ300?"

Seller: No...

Friends' buyer: "Do you know how to get to the [insert name of the nearest] metro station?" 